\title{
Lipoma-Preferred Partner
}

National Cancer Institute

\section{Source}

National Cancer Institute. Lipoma-Preferred Partner. NCI Thesaurus. Code C97612.

Lipoma-preferred partner ( $612 \mathrm{aa}, \sim 66 \mathrm{kDa}$ ) is encoded by the human LPP gene. This protein may be involved in cell motility or cell shape. 